\title{
Effect Of Direct Learning Method And Problem Solving Learning Method On High Jump Skill
}

\author{
Syahruddin $^{1)}$, Muhammad Syahrul Saleh ${ }^{2)}$, M. Sahib Saleh ${ }^{3)}$, Irmawati $^{4}$ \\ 1,2,3 Program Studi Pendidikan Jasmani, Kesehatan dan Rekreasi
}

Fakultas Ilmu Keolahragaan Universitas Negeri Makassar, Sulawesi Selatan Indonesia

Email: ${ }^{1}$ syahruddin@unm.ac.id, ${ }^{2}$ muh.syahrul.saleh@unm.ac.id,

${ }^{3}$ m.sahib.saleh@unm.acid

${ }^{4}$ Guru SMP Negeri 29 Makassar

Email: ${ }^{4}$ irmawatiaja71@gmail.com

\begin{abstract}
This study aims to determine is there any effect of direct learning methods (MPL) on high jump skills, is there any influence of problem solving learning methods (MPM) on high jump skills, and there are differences in the effect of direct learning methods $(M P L)$ and problem solving learning methods (MPM) on high jump skills. The research subjects were students SMP Negeri 29 Makassar and were randomly selected and 20 people were gathered, and made into two groups consisting of 10 people each group. The research used a pretest-posttest design. This research was conducted during eight meetings. Before treatment, samples were given in a process high jump of skill test, then were treated according to the methods of each group then after treatment were given a posttest. The results showed that there was a significant effect of MPL on high jumping of skills ( $p<0.05)$; there was a significant effect of MPM on increasing the high jump process of skills ( $p<0.05)$; and MPM significantly improved high jumping of skills than MPL $(p<0.05)$. The conclusion of this study 1) MPL improves high jumping skills, 2) MPM increases high jumping skills, and 3) MPM is better than MPL.
\end{abstract}

Keywords: Direct Learning Method, Problem Solving Learning Method, High Jump Skill

\section{Pengaruh Metode Pembelajaran Langsung Dan Metode Pembelajaran Pemecahan Masalah Terhadap Keterampilan Lompat Tinggi}

\begin{abstract}
ABSTRAK
Penelitian ini bertujuan untuk mengetahui apakah ada pengaruh metode pembelajaran langsung (MPL) terhadap keterampilan lompat tinggi, untuk mengetahui apakah ada pengaruh metode pembelajaran pemecahan masalah (MPM) terhadap keterampilan lompat tinggi, dan untuk mengetahui apakah ada perbedaan pengaruh metode pembelajaran langsung (MPL) dan metode pembelajaran pemecahan masalah (MPM) terhadap keterampilan lompat tinggi. Subjek penelitian adalah siswa SMP Negeri 29 Makassar dan dipilih secara random dan terkumpul 20 orang, dan dibuat menjadi dua kelompok terdiri atas 10 orang setiap kelompok. Penelitian menggunakan pretest-posttest design. Penelitian ini dilakukan selama delapan kali pertemuan. Sebelum perlakuan, sampel diberikan di tes keterampilan proses lompat tinggi, lalu diberi perlakukan sesuai metode masing-masing kelompok kemudian setelah perlakukan diberi posttest. Hasil penelitian menunjukkan bahwa ada pengaruh yang signifikan MPL terhadap keterampilan lompat tinggi $(\mathrm{p}<0.05)$; ada pengaruh yang signifikan MPM terhadap peningkatan keterampilan proses lompat tinggi ( $<<0.05)$; dan MPM lebih baik secara signifikan meningkatkan keterampilan proses lompat tinggi dari pada MPL $(\mathrm{p}<0.05)$. Simpulan penelitian ini 1) MPL meningkatkan keterampilan lompat tinggi, 2) MPM meningkatkan keterampilan lompat tinggi, dan 3) MPM lebih baik dari pada MPL.
\end{abstract}

Kata Kunci: Metode Pembelajaran Langsung, Metode Pembelajaran Pemecahan Masalah, Keterampilan Lompat Tinggi

Info Artikel

Dikirim

Diterima

Dipublikasikan
(C) 2020 IKIP BUDI UTOMO MALANG

P-ISSN 2613-9421

E-ISSN 2654-8003

Alamat korespondensi: syahruddin@unm.ac.id

Universitas Negeri Makassar, Jl. Wijaya Kusuma No.14, Banta-Bantaeng, Kec. Rappocini,

Kota Makassar, Sulawesi Selatan 90222, Indonesia 


\section{PENDAHULUAN}

Pendidikan jasmani merupakan aktivitas jasmani melalui pendidikan yang bermuara pada tumbuh kembang jasmani, mental, keterampilan, intelegensi, kebugaran, serta membentuk karakter. Pendidikan jasmani adalah satu fase dari proses pendidikan keseluruhannya yang peduli terhadap perkembangan dan penggunaan kemampuan gerak individu yang sifatnya sukarela serta bermakna dan terhadap reaksi yang langsung berhubungan dengan mental, emosional, dan sosial (Harsuki, 2013). Selain itu, pendidikan jasmani mengembangkan secara paripurna ranah psikomorik, kognitif, dan afektif yang selama ini sering terabaikan. Karena itu pelaksanaan pendidikan jasmani di sekolah peranan guru pendidikan jasmani sangat penting, sebab guru pendidikan jasmani membina dan mengembangkan keterampilan siswa.

Upaya pembinaan itu, dapat menentukan siswa menjadi cerdas, terampil dan memiliki perilaku yang baik. Dengan demikian, guru pendidikan jasmani mampu mengaplikasikan ilmu yang dimiliki terhadap tugas yang diembannya sehingga siswa yang ajar menjadi terampil seperti di materi ajar nomor lompat tinggi. Dalam kaitannya dengan materi nomor lompat tinggi, guru diharuskan memperhatikan tahapan-tahapan lompatan seperti proses berlari, menumpu, melayang dan mendarat. Tahap-tahap teknik lompat itu, diharapkan seorang guru harus cerdas dengan memanfaatkan berbagai metode pembelajaran dalam memecahkan masalah serta dalam pembelajaran siswa merasa tidak jenuh dan tertekan.

Untuk menghasilkan keterampilan dalam proses pembelajaran, salah satu yang memerang peranan adalah metode pembelajaran. Guru selayaknya memanfaatkan metode belajar sehingga proses pembelajaran di kelas dapat terlaksana dan berdaya guna serta siswa memperoleh ilmu pengetahuan dan keterampilan. Guru pendidikan jasmani harus berusaha seoptimal mungkin untuk mempengaruhi siswa dalam proses pembelajaran. (Syahruddin, 2016b) . Implementasi dalam metode pembelajaran terhadap keterampilan sangat ditentukan kompetensi guru. Seperti halnya, guru menggunakan dapat berbagai metode pembelajaran antara lain metode pembelajaran langsung (direct instruction), metode pembelajaran pemecahan masalah (problem solving 
learning), pendekatan pengetahuan keterampilan (knowledge-skill approach), metode pendekatan belajar gerak (motor learning), metode pendekatan bermain, metode pendekatan demonstrasi dan metode pendekatan komando. (Ahyat, 2017)

Metode pembelajaran langsung adalah salah satu pendekatan mengajar yang dirancang khusus untuk menunjang proses belajar siswa yang berkaitan dengan pengetahuan deklaratif dan pengetahuan prosedural yang terstruktur dengan baik yang dapat diajarkan dengan pola kegiatan yang bertahap (Sundawan, 2016). Artinya bahwa metode pembelajaran langsung dimaksudkan untuk membantu siswa mempelajari keterampilan dasar dan secara elementer.

Metode pembelajaran langsung dapat membantu siswa dalam mempelajari keterampilan dasar dan memperoleh informasi yang dapat diajarkan secara elementer (supply, 2005). Metode pembelajaran langsung digunakan untuk menyampaikan pelajaran yang ditransformasikan langsung oleh guru kepada siswa (Suherman, 2014). Dalam materi lompat tinggi dengan menggunakan metode pembelajaran langsung (MPL) siswa diajar secara bertahap selangkah demi selangkah teknik-teknik yang ada pada setiap keterampilan lompat tinggi dimulai dari cara mengambil awalan, sikap badan dan ektremitas inferior pada waktu akan menolak, bagaimana badan dan anggota tubuh ketika melewati mistar, dan sikap akhir.

Selanjutnya metode pembelajaran pemecahan masalah adalah metode pembelajaran yang diaplikasikan oleh guru pada siswa dan siswa berupaya memecahkan masalah yang ditemukan dengan mengerahkan segala kemampuan yang ada pada diri siswa tersebut (Indarwati et al., 2014). Dalam aplikasi metode pembelajaran pemecahan masalah (MPM) guru tetap memiliki peranan terutama dalam menentukan tugas gerak yang akan dilakukan oleh siswa. Metode problem solving (metode pemecahan masalah) merupakan metode pembelajaran yang dilakukan dengan memberikan suatu permasalahan, yang kemudian dicari penyelasainnya dengan dimulai dari mencari data sampai pada kesimpulan. (Ahyat, 2017)

Metode pembelajaran pemecahan masalah terdiri atas menemukan fakta, menemukan masalah, menemukan gagasan, menemukan solusi, dan menemukan penerimaan (Mardhiyana \& Sejati, 2016). Metode pembelajaran pemecahan 
masalah adalah suatu metode pembelajaran yang memusatkan pada pengajaran dan keterampilan pemecahan masalah, yang diikuti dengan penguatan keterampilan (Rosy \& Pahlevi, 2015). Metode pembelajaran pemecahan masalah adalah suatu metode pembelajaran yang bertujuan melatih siswa merumuskan solusi dari masalah yang ada dan membiasakan siswa berpikir analitis (Halim, 2016).

Dalam pembelajaran materi lompat tinggi, permasalahan yang sering ditemukan oleh para guru adalah dalam melakukan teknik-teknik lompat tinggi yaitu: terjadi penurunan kecepatan yang sangat drastis pada saat awalan, minim dorongan dari ektremitas inferior, ektremitas inferior tidak diangkat setinggitingginya, lengan tidak relaks dan tidak diangkat ke atas sehingga bisa melewati mistar, pinggang dan badan tidak memutar ketika berada di udara kedepan. Terkait dari kedua metode pembelajaran yang dikemukakan, penulis ingin menggunakan dua metode, yaitu metode pembelajaran langsung (MPL) dan metode pembelajaran pemecahan masalah (MPM). MPL dan MPM dalam pembelajaran lompat tinggi, siswa bisa lebih mudah menguasai keterampilan dan juga membentuk proses kerja sama siswa dan guru serta tercipta atmosfir akademik. Pembelajaran dikatakan baik dan efektif apabila ada metode yang tepat untuk memberikan peluang terjadinya proses pembelajaran yang berhasil guna untuk mencapai hasil belajar optimal. (Syahruddin, 2016a)

Berdasarkan observasi dan indentifikasi lapangan di SMP Negeri 29 Makassar dalam pembelajaran pendidikan jasmani nomor lompat tinggi penguasaan siswa masih rendah karena masih banyak siswa yang kurang mampu melakukan proses gerakan-gerakan dasar lompat tinggi antara lain pada saat tumpuan, melayang dan mendarat

\section{METODE}

Penelitian ini adalah penelitian eksperimen dengan desain randomized group pretest-postest. Populasi adalah siswa SMP Negeri 29 Makassar sedangkan jumlah sampel 20 orang, selanjutnya dibagi dua, yaitu kelompok MPL dan kelompok MPM. 
Variabel independent terdiri atas: metode pembelajaran langsung (MPL) dan metode pembelajaran pemecahan masalah (MPM), sedangkan variabel dependent adalah keterampilan lompat tinggi.

Tabel 1. Instrumen Kisi-Kisi Gerakan.

\begin{tabular}{|c|c|c|c|}
\hline No & Indikator & Butir Tes & Keterangan \\
\hline 1 & Awalan & $\begin{array}{l}\text { Sampel melakukan gerakan } \\
\text { lari untuk awalan }\end{array}$ & $\begin{array}{ll}\text { Kebenaran } & \text { melakukan } \\
\text { teknik awalan lari untuk } \\
\text { awalan }\end{array}$ \\
\hline 2 & Tolakan & $\begin{array}{l}\text { Sampel melakukan gerakan } \\
\text { melompat }\end{array}$ & $\begin{array}{l}\text { Kebenaran melakukan } \\
\text { teknik gerakan melompat }\end{array}$ \\
\hline 3 & Melayang & $\begin{array}{l}\text { Sampel melakukan gerakan } \\
\text { saat badan melayang untuk } \\
\text { melewati mistar }\end{array}$ & $\begin{array}{l}\text { Kebenaran melakukan } \\
\text { teknik gerakan saat badan } \\
\text { melayang }\end{array}$ \\
\hline 4 & Mendarat & $\begin{array}{l}\text { Sampel melakukan teknik } \\
\text { gerakan saat mendarat }\end{array}$ & $\begin{array}{l}\text { Kebenaran melakukan } \\
\text { teknik gerakan saat } \\
\text { mendarat }\end{array}$ \\
\hline
\end{tabular}

Penelitian ini menggunakan tes keterampilan proses lompat tinggi yang dibuat peneliti dengan kisi-kisi instrument seperti pada Tabel 1. Prosedur pengumpulan data dilakukan dengan jalan melaksanakan pretest lompat tinggi untuk melihat keterampilan proses lompat tinggi. Selanjutnya diberi perlakuan pada masing-masing kelompok selama delapan kali pertemuan, setelah perlakuan dilakukan posttest atau tes yang sama dengan pretest. Data yang terkumpul dianalisis statistika uji-t berpasangan dan tidak berpasangan dengan taraf kepercayaan $95 \%$.

\section{HASIL DAN PEMBAHASAN}

Deskriptif data pretest dan posttest keterampilan lompat tinggi kelompok MPL dan kelompok MPM lihat tabel 2.

Tabel 2. Deskripsi Pretest dan Posttest Kelompok MPL dan Kelompok MPM

\begin{tabular}{|c|c|c|c|c|c|c|}
\hline \multirow{3}{*}{ Statistik } & \multicolumn{6}{|c|}{ Metode } \\
\hline & \multicolumn{3}{|c|}{ MPL } & \multicolumn{3}{|c|}{ MPM } \\
\hline & $\mathrm{T} 1$ & $\mathrm{~T} 2$ & Beda & $\mathrm{T} 1$ & $\mathrm{~T} 2$ & Beda \\
\hline $\mathbf{N}$ & 10 & 10 & 10 & 10 & 10 & 10 \\
\hline Mean & 45.00 & 64.20 & 19.20 & 45.10 & 74.60 & 29.50 \\
\hline SD & 3.055 & 3.615 & 3.393 & 3.872 & 3.134 & 2.838 \\
\hline Minimim & 41 & 58 & 14 & 40 & 70 & 25 \\
\hline Maksimum & 51 & 69 & 26 & 51 & 79 & 35 \\
\hline Sum & 450 & 642 & 192 & 451 & 746 & 295 \\
\hline
\end{tabular}


Hasil analisis uji-t berpasangan dari keterampilan proses lompat tinggi kelompok MPL dan kelompok MPM, dapat lihat tabel dibawah ini.

Tabel 3. Hasil Uji-t berpasangan Masing-masing Kelompok

\begin{tabular}{cccc}
\hline Metode & t-hit $_{\text {-h }}$ & df & Sign \\
\hline MPL & 17.895 & 9 & 0.000 \\
MPM & 32.868 & 9 & 0.000 \\
\hline
\end{tabular}

Berdasarkan Tabel 3, hasil analisis keterampilan lompat tinggi antara pretest dan posttest pada kelompok MPL diperoleh nilai $17.895(\mathrm{p}<\alpha 0.05)$ atau ada perbedaan rata-rata sebelum dan sesudah mengikuti MPL terhadap keterampilan lompat tinggi. Selanjutnya keterampilan proses lompat tinggi antara pretest dan posttest pada kelompok MPM diperoleh nilai $32.868(\mathrm{p}<\alpha 0.05)$ atau ada perbedaan rata-rata sebelum dan sesudah mengikuti MPM terhadap keterampilan lompat tinggi.

Tabel 4. Hasil Analisis Uji-t antara Kelompok MPM dan MPL

\begin{tabular}{llll}
\hline \multicolumn{1}{c}{ Variabel } & t-hit & df & sign \\
\hline $\begin{array}{l}\text { Nilai Selisih MPM - Nilai } \\
\text { MPL }\end{array}$ & -6.874 & 18 & .000 \\
\hline
\end{tabular}

Berdasarkan tabel 4, ditemukan ada perbedaan keterampilan lompat ting gi antara MPL dan MPM diperoleh nilai sebesar $-6.874(\mathrm{p}<\alpha$ 0.05) atau ada perbedaan rata-rata antara MPL dan MPM terhadap keterampilan lompat tinggi. MPM lebih baik meningkatkan keterampilan lompat tinggi dari pada MPL (X MPM $=29.50>$ X MPL $=19.20)$.

Sejalan dengan hasil analisis uji-t berpasangan ditemukan bahwa ada pengaruh MPL terhadap keterampilan lompat tinggi $(\mathrm{p}<0.05)$. Perubahan ini terjadi setelah siswa mengikuti proses pembelajaran selama delapan kali pertemuan melalui penerapan MPL. Perubahan yang di maksud adalah adanya peningkatan keterampilan proses gerak mulai dari tahap mengambil awalan sampai sampai pada tahap pendaratan. Terjadinya peningkatan keterampilan lompat tinggi karena siswa ketika belajar dengan penerapan MPL, diajar secara bagian per bagian tentang teknik lompat tinggi. Dengan penerapan MPL, terjadi pengawasan yang ketat untuk mencapai kesempurnaan teknik dan kematangan gerak lompat tinggi.

Belajar keterampilan proses lompat tinggi dengan penerapan MPL selain dapat meningkatkan gerakan otomatisasi gerakan juga dapat menyebabkan 
meningkatnya unsur kondisi fisik, yaitu kekuatan. Ketika siswa mengikuti pembelajaran lompat tinggi terjadi tonus pada otot ekstremitas inferior setiap kali mengangkat atau menolak tubuh ke arah atas, karena badan merupakan bagian dari tahanan internal. Dengan memiliki ektremitas inferior yang kuat, diharapkan dapat menunjang keberhasilan gerakan khas dari teknik-teknik olahraga tersebut

Selain peningkatan keterampilan dan kekuatan melalui penerapan MPL, terjadi juga otomatisasi gerakan. Dengan berlatih selama beberapa hari seseorang memasuki tahap otomatisasi. Automatic motion is the ability of students to make movements even though students are simultaneously doing cognitive activities (Dennett \& Hallett, 2007). Artinya, gerakan siswa sudah berkembang dengan baik dan mampu mengontrol gerak dalam waktu yang singkat, dan setiap gerakan yang dilakukan berdaya guna, bahkan gerakan yang dilakukan nampak rileks. Dengan adanya otomatisasi gerakan, keterampilan lompat tinggi mengalami peningkatan. Model pembelajaran langsung (direct instruction) mampu memberikan pengalaman belajar, selain itu pembelajaran dengan model pembelajaran langsung, siswa cukup aktif dalam memperhatikan penjelasan guru dan aktif melakukan tugas dari guru. (Asri, 2016)

Model Pengajaran langsung adalah salah satu pendekatan mengajar yang dirancang khusus untuk menunjang proses belajar siswa yang berkaitan dengan pengetahuan deklaratif dan pengetahuan prosedural yang terstruktur dengan baik yang dapat diajarkan dengan pola kegiatan yang bertahap, selangkah. Pembelajaran langsung dapat meningkatkan keterampilan siswa dalam pembelajaran Penjaskes. (Tenaga Surbakti, 2015). Selain itu, penelitian terdahulu mengemukakan bahwa penerapan model pembelajaran langsung memberikan peningkatan kemampuan meroda siswa sebesar 25\%. (Yantari, 2014)

MPL digunakan guru untuk menyampaikan yang ditransformasikan kepada siswa secara langsung bagian per bagian. Dalam implementasinya dilakukan kontrol secara ketat terhadap kemajuan belajar. Arahan dan pengawasan dalam pengembangan MPL terutama dilakukan ketika menjelaskan tentang latihanlatihan yang akan dilakukan oleh siswa. Selain itu, dalam penerapan metode ini terjadi hal-hal positif dalam proses pembelajaran, seperti: materi terstuktur, penjelasan kepada siswa, demonstrasik melalui latihan, siswa berlatih menerapkan 
konsep yang dipelajari serta memberi feedback. Oleh kerena itu, dapat dikemukakan bahwa bahwa MPL dapat meningkatkan proses keterampilan lompat tinggi.

Kemudian, hasil analisis uji-t pada kelompok MPM ditemukan ada pengaruh MPM terhadap keterampilan lompat tinggi $(\mathrm{p}<0.05)$. Siswa setelah mengikuti proses pembelajaran selama delapan kali pertemuan melalui penerapan MPM, terjadi peningkatan keterampilan lompat tinggi. Dalam penerapan MPM, guru memiliki peranan terutama menetapkan tugas gerak apa yang akan dilaksanakan siswa dalam kaitannya dengan pemecahan masalah dalam proses pembelajaran. Dalam MPM siswa dituntut proaktif dan kreatif.

Proses pembelajaran dengan MPM peran aktif siswa nampak, seperti aktif bertanya, mencari solusi, dan daya cipta tentang bagaimana menciptakan gerakan yang sempurna. Peningkatan keterampilan lompat tinggi melalui MPM karena metode tersebut memiliki struktur pelaksanaan yang baik. Pecahkan masalah yang terjadi pada setiap gerak kemudian memperbaiki kesalahan (Sari, 2016). Dengan peran aktif dan kreativitas yang dilakukan siswa dalam memperbaiki kesalahan yang terjadi pada pembelajaran lompat tinggi menyebabkan peningkatan terhadap keterampilan lompat tinggi.

Belajar dengan penerapan MPM juga dapat meningkatkan kekuatan. Seiring dengan terjadinya tegangan pada otot nampak ketika siswa mengambil awalan dan menumpu untuk melolak badan ke arah atas. Dengan memiliki ektremitas inferir yang kuat, akan dapat dapat menunjang keterampilan dalam cabang olahraga. Artinya kekuatan sangat menunjang keberhasilan gerakan. Semakin tinggi tingkat kekuatan, akan semakin baik cara untuk menampilkan gerakan.

Otomatisasi gerakan dapat tercipta dengan belajar melalui penerapan MPM. Dengan otomatisasi gerakan itu, siswa dapat mendemonstrasikan tahapan gerakan lompat tinggi dengan baik tanpa perlu lagi untuk berpikir terhadap apa yang akan dilakukan. Memiliki otomatisasi gerakan, akan menghasilkan gerak yang konsisten, halus, dan stabil.

Penerapan MPM juga melatih siswa untuk merancang temuannya, berpikir dan bertindak inovatif, melakukan penyelidikan dan melakukan pengamatan. Dalam metode ini, pemahaman konsep gerak dapat tercapai dengan baik. Gerak 
tersebut tidak dihafal karena ditemukan oleh siswa sendiri dan menjadi gerak otomatisasi.

MPM dapat juga memberikan siswa pengalaman. Dengan pengalaman dapat digunakan untuk memecahkan masalah, mengembangkan keterampilan berpikir, kemandirian dan percaya diri. Siswa diberi keleluasaan untuk bertanya, belajar berkelompok atau berpasangan sehingga terjadi kerja sama antar siswa untuk memecahkan masalah tentang tugas gerak. Dengan demikian, dapat dikemukakan bahwa MPM dapat meningkatkan keterampilan lompat tinggi. Walau metode ini telah banyak diciptakan dalam berbagai bentuknya namun langka dibidang pendidikan jasmani dan kesehatan (Purwanto, 2006). Hasil penelitian terdahulu menunjukkan penerapan pembelajaran problem solving dapat meningkatkan pemahaman siswa yang lebih mendalam pada materi pembelajaran PJOK (Yuditya Putra Handiono Sudarso, 2017). Metode pemecahan masalah (problem solving) bukan hanya sekedar metode mengajar, tetapi juga merupakan suatu metode berpikir, sebab dalam metode pemecahan masalah (problem solving) dapat menggunakan metode-metode lainnya yang dimulai dari mencari data sampai menarik kesimpulan. (Ikmal, Eka Supriatna, 2018). Karena orientasi dari MPM adalah investigasi dan penemuan (Hamiyah \& Jauhar, 2014).

Students have deeper understanding of the theories through the application of theories to solving real problems related to recreation and physical education. (Chan \& Luk, 2013). Siswa memiliki pemahaman yang lebih dalam tentang teori melalui penerapan teori problem solving yang berhubungan dengan pendidikan jasmani dan rekreasi.

Berdasarkan analisis data perbedaan kedua kelompok, ditemukan MPM mempunyai pengaruh yang lebih besar terhadap keterampilan lompat tinggi dari pada MPL $(\mathrm{p}<0.05)$.

MPM memiliki intensitas belajar lebih tinggi daripada MPL. Karena MPM siswa diberi kesempatan untuk bertanya lalu memecahkan masalah yang ada pada dirinya kemudia mendemostrasikan secara berulang-ulang. Semakin banyak kerja yang dilakukan per satuan waktu, makin tinggi intensitasnya. (Nala, 1998). MPM memiliki intensitas kerja yang lebih tinggi karena siswa diberi kebebasan dalam melakukan gerakan sehingga peran aktif dan kretivitas siswa nampak ketika 
mencari solusi sebagai pemecahan untuk menguasai gerakan. Siswa juga nampak termotivasi dan tertantang dalam mempelajari tahapan lompat tinggi. Sedangkan pada MPL, siswa mempelajari tahapan lompat tinggi intensitas kerja lebih sedikit, hal ini terjadi karena dalam MPL proses pembelajaran centre of teacher sehingga peran aktif siswa terbatas. Sedangkan penerapan MPM, centre of student, guru sebagai fasilitator sehingga menyebabkan siswa proaktif dan memperlihatkan kreativitas yang tinggi yang menyebabkan pemahaman dan pengalaman pada penguasaan keterampilan gerak yang semakin baik. Hal ini sesuai dengan penelitian sebelumnya bahwa some students preferred to learn the knowledge and get the answers to the questions/problems from the teachers and books rather than from an active learning approach (Chan \& Luk, 2013). Pemecahan masalah merupakan cara memberikan pengertian atau pembelajaran dengan menstimulasi anak didik untuk memperhatikan (Nugraha et al., 2019). Menelaah dan berpikir tentang sesuatu masalah untuk selanjutnya menganalisis masalah tersebut sebagai upaya untuk memecahkan masalah.

Metode pemecahan masalah (problem solving) bukan hanya sekedar metode mengajar, tetapi juga merupakan suatu metode berpikir, sebab dalam metode pemecahan masalah (problem solving) dapat menggunakan metode-metode lainnya yang dimulai dari mencari data sampai menarik kesimpulan. (Djamrah, 2010). Dipertegas oleh penelitian terdahulu bahwa untuk mendapatkan hasil belajar penjas yang baik hendaknya guru merancang sebuah model pembelajaran yang didalamnya terdapat materi-materi pengembangan gerak sehingga pada saat siswa melakukan pembelajaran dapat mengembangkan secara langsung kinestetik (gerak) siswa dan akan berguna serta dapat diaplikasikan pada saat proses. (Syahruddin dkk, 2019)

\section{SIMPULAN}

Berdasarkan hasil pengujian hipotesis dan pembahasan dapat disimpulkan: 1) MPL meningkatkan keterampilan lompat tinggi, 2) MPM meningkatkan keterampilan lompat tinggi, dan 3) MPM lebih baik daripada MPL. 


\section{DAFTAR RUJUKAN}

Ahyat, N. (2017). EDUSIANA: Jurnal Manajemen dan Pendidikan Islam. Edusiana: Jurnal Manajemen Dan Pendidikan Islam, 4(1), 24-31. https://doi.org/https://doi.org/10.30957/edusiana.v4i1.5

Asri. (2016). Peningkatan Pembelajaran Passing Bawah dalam Permainan Bola voli melalui Model Pembelajaran Langsung (Dircet Instructions) pada siswa kelas V SDN No. 1 Pesaku Kecamatan Dolo Barat Kabupaten Sigi. Tadulako Journal Sport Science and Physical Education, 4(1), 1-15.

Chan, K., \& Luk, E. K. (2013). HKBU Institutional Repository adolescents. 14, $167-179$.

Dennett, D. C., \& Hallett, M. (2007). Free Will: Now You Have It, Now You Don ' $t$. New York.

Halim, S. dan. (2016). Penerapan Metode Problem Solving Pada Pembelajaran IPA Untuk Peningkatan Kemampuan Berpikir Kritis Siswa (Penelitian Tindakan Kelas Siswa Kelas V di SDN 3 Kreo Tangerang). ISBN: 978-9793649-96-2. Prosiding Seminar Nasional Multi Disiplin Ilmu \& Call for Papersunisbank (Sendi_U) Ke-2 Tahun 2016.

Harsuki. (2013). Pengantar Manajemen Olahraga. In Pt. Raja Grafindo Persada. https://doi.org/10.1017/CBO9781107415324.004

Ikmal, Eka Supriatna, A. T. (2018). Pengaruh Metode Problem Solving Terhadap Pembelajaran Passing Bawah Bola Voli. Jurnal Pendidikan Dan Pembelajaran Khatulistiwa, 7(3), 1-8.

Indarwati, D., Wahyudi, W., \& Ratu, N. (2014). Peningkatan Kemampuan Pemecahan Masalah Matematika Melalui Penerapan Problem Based Learning Untuk Siswa Kelas V SD. Satya Widya. https://doi.org/10.24246/j.sw.2014.v30.i1.p17-27

Mardhiyana, D., \& Sejati, E. O. W. (2016). Mengembangkan Kemampuan Berpikir Kreatif dan Rasa Ingin Tahu Melalui Model Pembelajaran Berbasis Masalah. PRISMA, Prosiding Seminar Nasional Matematika. (pp. 672-688).

Nugraha, J., MS, Z., \& Fuad, N. (2019). Peningkatan Keterampilan Menulis Deskripsi Melalui Pendekatan Saintifik Dengan Metode Problem Based Learning Di Kelas IV Sekolah Dasar. Prosiding Seminar Nasional Pendidikan KALUNI. (Vol. 2).https://doi.org/10.30998/prokaluni.v2i0.37

Purwanto, S. (2006). Pentingnya Pelaksanaan Administrasi Pembelajaran Pendidikan Jasmani Di Smu. Jurnal Pendidikan Jasmani Indonesia, 5(1), 14-20.

Rosy, B., \& Pahlevi, T. (2015). Penerapan Problem Based Learning Untuk Meningkatkan Kemampuan Berpikir Kritis Dan Keterampilan Memecahkan Masalah. In Prosiding Seminar Nasional Pendidikan Ekonomi FE UNY "Profesionalisme Pendidik dalam Dinamika Kurikulum Pendidikan di 
Indonesia pada Era MEA.

Sari, S. (2016). Mengatasi DOMS Setelah Olahraga. Motion: Jurnal Riset Physical Education. 7(1), 97-107.

Suherman, A. (2014). implementasi Kurikulum Baru Tahun 2013 Mata Pelajaran Pendidikan Jasmani. Mimbar Sekolah Dasar. 1(1), 71-76.

Sundawan, M. D. (2016). Perbedaan Model Pembelajaran Konstruktivisme Dan Model Pembelajaran Langsung. Jurnal Logika. 16(1).

Supply. (2005). Pemanfaatan Media Visual dalam Menunjang Pembelajaran Pendidikan Jasmani di Sekolah Dasar. Jurnal Pendidikan Jasmani Indonesia. $3(1)$.

Syahruddin. (2016a). Pengaruh Metode Pembelajaran Dan Kelincahan Terhadap Keterampilan Bermain Bola Basket. Jurnal Pedagogik Keolahragaan, 02(2), $1-19$.

Syahruddin, A. S. (2016b). The Effect Of Exercise Style Of Teaching And Command Styles Of Teaching To Over Passing Of Skills Volly ball. Jurnal Pedagogik Keolahragaan, 02(01), 11-22.

Syahruddin dkk. (2019). Pengaruh kinsetetik, sikap, dan motivasi terhadap hasil belajar pendidikan jasmani. Jurnal SPORTIF: Jurnal Penelitian Pembelajaran, 5(2), 232-248.

Tenaga Surbakti. (2015). Peningkatan Keterampilan bermain Bulutangkis siswa Melalui Penerapan Pembelajarn Langsung di Kelas IV SD Negeri 040475 Tiga Serangkai. Journal PGSD FIP UNIMED, 4(2), 178-190.

Yantari, O. D. (2014). Peningkatan Hasil Belajar Meroda Melalui Model Pembelajaran Langsung. Jurnal Pendidikan Olahraga Kesehatan UNESA, 2(1), 219-222.

Yuditya Putra Handiono Sudarso. (2017). Pengaruh Metode Pembelajaran Problem Solving Terhadap Ketuntasan Hasil Belajar Dribble Bola Basket Dalam Pembelajaran Pendidikan Jasmani, Olahraga dan Kesehatan. Jurnal Pendidikan Olahraga Dan Kesehatan, 5(3), 589-594. 